\title{
Effects of potassium, sodium and chloride fertiliser rates on fodder beet yield and quality in Canterbury
}

\author{
E. CHAKWIZIRA ${ }^{1}$, E.D. MEENKEN ${ }^{1}$, S. MALEY ${ }^{1}$, M. GEORGE ${ }^{1}$, R. HUBBER ${ }^{1}$, \\ J. MORTON ${ }^{2}$ and A. STAFFORD ${ }^{2}$ \\ ${ }^{I}$ The New Zealand Institute for Plant \& Food Research Limited, Lincoln, New Zealand \\ ${ }^{2}$ Ballance Agri-Nutrients Ltd, Mount Maunganui, Tauranga, New Zealand
}

Emmanuel.Chakwizira@plantandfood.co.nz

\begin{abstract}
There is renewed interest in fodder beet (Beta vulgaris L.) production in the South Island of New Zealand. However, recommended agronomic practices for maximising productivity and quality are limited. Two experiments investigating the effects of different rates $(\mathrm{kg} / \mathrm{ha})$ of potassium $(\mathrm{K} ; 150$ or 300$)$, sodium $(\mathrm{Na} ; 100$ or 200$)$ and chloride $(\mathrm{Cl} ; 240)$ fertiliser application on fodder beet dry matter (DM) production, nutrient concentration and uptake were carried out at Southbridge (2011) and Bankside (2012), Canterbury, New Zealand. Final DM yield was unaffected by the treatments: averaging $32 \mathrm{t} \mathrm{DM} / \mathrm{ha}$ at Southbridge and $21 \mathrm{t} \mathrm{DM} / \mathrm{ha}$ at Bankside. However, there was a significant interaction between $\mathrm{K}$ and both $\mathrm{Cl}$ and $\mathrm{Na}$, on DM yield at Southbridge. Specifically, yield increased to $38 \mathrm{t} \mathrm{DM} /$ ha with $\mathrm{Na}$ and decreased to 30 t DM/ha with $\mathrm{Cl}$, in the presence of $\mathrm{K}$. Application of $\mathrm{K}, \mathrm{Na}$, and $\mathrm{Cl}$ fertiliser increased the respective tissue mineral concentration and respective total uptake for both the bulb and shoot components. Potassium tended to depress crude protein, neutral detergent fibre and ash content of the bulbs and increase the metabolisable energy and soluble sugar. The combination of low fibre and high soluble sugar concentrations puts animals at risk of rumen acidosis. These results suggest that fodder beet crops subjected to high rate of soil and/ or fertiliser K should be supplemented with feed high in crude protein and fibre.
\end{abstract}

Key words: Beta vulgaris L., agronomic practices, mineral concentration, mineral uptake, quality attributes.

\section{Introduction}

There is renewed interest in fodder beet (Beta vulgaris L.) production in the South Island of New Zealand, especially a strong shift toward use of fodder beet for winter feeding of South Island dairy herds. There is an estimated 6000-10 000 ha of fodder beet grown annually in New Zealand (Chakwizira et al. 2012; Matthew et al. 2011). Recent research suggests high dry matter (DM) yields of 19-35 t DM/ha (Chakwizira et al. 2012; Matthew et al. 2011) are attainable in New Zealand. These DM yields are higher than the 10-15 t $\mathrm{DM} /$ ha for the traditional winter crops, e.g., kale and swedes (Chakwizira et al. 2011; Gowers et al. 2006; Wilson et al. 2006). The potential to grow more DM per unit area has been the key driver in recent increases in the area under fodder beet production, particularly for the increasing New Zealand dairy herd in the South Island.

In fodder beet, recommended agronomic practices for maximising productivity and quality are under review, especially as crops need to be managed for minimal environmental impact. Stephen et al. (1980), working with complete mixtures of nutrients, showed that both bulb and shoot DM were affected by the withdrawal of nitrogen, phosphorus and sodium (Na), but did not respond to the withdrawal of other nutrients. Relevant local research on the effects of chloride fertilisers (Goh \& Magat 1989; Magat \& Goh 1988), has demonstrated increased tissue mineral concentration and uptake of potassium $(\mathrm{K}), \mathrm{Na}$ and chloride $(\mathrm{Cl})$ but with variable and inconsistent DM yield response. Although these data are important in understanding the growth requirements for fodder beet in New Zealand, it is not clear whether these responses are due to the effects of single elements or their interactions. Chakwizira et al. (2012) showed that $\mathrm{Cl}$ application reduced DM yield in the presence of K, contrary to previous reports (Magat $\&$ Goh 1988). There is also limited information on the nutritive qualities of fodder beet crops in New Zealand, with the current reports suggesting metabolisable energy (ME) of $\geq 13 \mathrm{MJ} / \mathrm{kg} \mathrm{DM}$, crude protein (CP) of $<10 \%$ DM (Gibbs 2011; Matthew et al. 2011), soluble sugars (SS) of $>60 \%$ DM and neutral detergent fibres (NDF) of about 13\% DM (Matthew et al. 2011). These values are comparable with those reported overseas (Clark et al. 1987). Clark et al. (1987) have also reported acid detergent fibre (ADF), dry organic matter digestibility (DOMD) and total ash content of $6.8,83.1$ and $7.5 \% \mathrm{DM}$, respectively. The primary objective of this study was to investigate the effects of $\mathrm{K}, \mathrm{Na}$ and $\mathrm{Cl}$ applications and their interactions on fodder beet DM yield, mineral composition and uptake. 


\section{Materials and methods}

The two experiments were located at Southbridge $\left(43^{\circ} 81^{\prime} \mathrm{S}, 172^{\circ} 25^{\prime} \mathrm{E}\right)$ on an immature Pallic soil (McLaren et al. 2009) in 2010/2011 season and Bankside $\left(43^{\circ} 69^{\prime} \mathrm{S}\right.$, $\left.171^{\circ} 97^{\prime} \mathrm{E}\right)$, on a Rakaia stony sandy loam soil (Hedley et al. 2010) in 2011/2012 season in Canterbury, New Zealand. The Southbridge site had been under perennial ryegrass (Lolium perenne L.) pasture between 2005 and 2008, and maize (Zea mays L.) followed by triticale ( $x$ Triticosecale Wittm. ex Camus) in the 2009/10 season. Soil preparation involved conventional cultivation after deep ploughing.

The Southbridge experiment was a randomised complete block design, with nine treatments (Table 1), replicated four times. Seed of fodder beet cv. 'Colosse' was planted on 1 November 2010 with an onion seed drill, at a row spacing of $375 \mathrm{~mm}$ to give a plant population of $120000 \mathrm{plants} / \mathrm{ha}$. Plot sizes were four rows $(1.5 \mathrm{~m})$ wide $\times 15 \mathrm{~m}$ long, giving a total experimental area of $0.081 \mathrm{~h}$. A soil test to $150 \mathrm{~mm}$ depth showed that the initial soil fertility was adequate, except for $\mathrm{K}$ (Table 2). Basal fertiliser was applied at $250 \mathrm{~kg} / \mathrm{ha}$ diammonium phosphate (DAP; 18:20:0:2) and $15 \mathrm{~kg} /$ ha boronate $(10 \% \mathrm{~B})$. Nitrogen was applied as urea $(46 \% \mathrm{~N})$ at $50 \mathrm{~kg} \mathrm{~N} / \mathrm{ha}$ twice, on 15 and 30 December 2010, respectively.

The nine fertiliser treatments (Table 1) were broadcast to the relevant plots 2 days after sowing, followed by a
$10 \mathrm{~mm}$ irrigation to dissolve the fertiliser into the soil. The treatments consisted of a range of $\mathrm{K}, \mathrm{Na}$ and $\mathrm{Cl}$ application rates. The total nutrient applied was $\mathrm{K}$ at 150 or $300 \mathrm{~kg} / \mathrm{ha}$ to the relevant plots, $\mathrm{Na}$ at 100 or $200 \mathrm{~kg} / \mathrm{ha}$ and $\mathrm{Cl}$ at $240 \mathrm{~kg} / \mathrm{ha}$ to the relevant plots. The different nutrients were sourced from different fertilisers. For example, $\mathrm{K}$ was obtained from potassium chloride $(\mathrm{KCl} ; 52 \% \mathrm{~K}, 48 \% \mathrm{Cl})$ and potassium sulphate $\left(\mathrm{K}_{2} \mathrm{SO}_{4}\right.$; $45 \% \mathrm{~K})$, Na was obtained from sodium chloride $(\mathrm{NaCl}$; $40 \% \mathrm{Na}$ and $60 \% \mathrm{Cl})$ and sodium sulphate $\left(\mathrm{Na}_{2} \mathrm{SO}_{4}\right.$; $32 \% \mathrm{Na}$ ). The chloride component of both the $\mathrm{K}$ and $\mathrm{Na}$ fertilisers, together with calcium chloride $\left(\mathrm{CaCl}_{2}\right.$; $36 \% \mathrm{Ca}$ and $64 \% \mathrm{Cl}$ ) were the sources of the chloride nutrient. Gypsum was applied in varying amounts to all plots, excluding the controls (Table 1). This was done to make sure all plots received the same amount of $\mathrm{Ca}$ and sulphate, which were in some of the applied fertilisers contributing to the $\mathrm{K}, \mathrm{Na}$, and $\mathrm{Cl}$ elements.

Total rainfall at Southbridge during the experimental period was $393 \mathrm{~mm}$. An addition $200 \mathrm{~mm}$ was added as irrigation throughout the experimental period. The mean temperature was $14.9^{\circ} \mathrm{C}$, with the highest temperature of $34.1^{\circ} \mathrm{C}$ recorded on 6 February 2011 and the lowest temperature of $1.9^{\circ} \mathrm{C}$ recorded on 31 March 2011 .

The Bankside experimental site had been under perennial ryegrass pasture for the previous 5 years. Soil preparation here also involved conventional cultivation after deep ploughing. The methodology

Table 1 The treatment structure and rate of individual minerals applied in fodder beet crops grown at Southbridge and Bankside in Canterbury, in 2010/11 and 2011/12 seasons, respectively.

\begin{tabular}{llccc}
\hline & \multicolumn{2}{c}{ Treatment } & \multicolumn{3}{c}{ Mineral application rate (kg/ha) } \\
Number & Structure ${ }^{1}$ & $\mathbf{K}$ & $\mathbf{N a}$ & $\mathbf{C l}$ \\
\hline 1 & Control & 0 & 0 & 0 \\
2 & Control+ Gypsum & 0 & 0 & 0 \\
3 & $200 \mathrm{Na}+$ Gypsum & 0 & 200 & 0 \\
4 & $300 \mathrm{~K}+$ Gypsum & 300 & 0 & 0 \\
5 & $240 \mathrm{Cl}+$ Gypsum & 0 & 0 & 240 \\
6 & $300 \mathrm{~K}, 200 \mathrm{Na}+$ Gypsum & 300 & 200 & 0 \\
7 & $100 \mathrm{Na}, 240 \mathrm{Cl}+$ Gypsum & 0 & 100 & 240 \\
8 & $150 \mathrm{~K}, 240 \mathrm{Cl}+$ Gypsum & 150 & 0 & 240 \\
9 & $150 \mathrm{~K}, 100 \mathrm{Na}, 240 \mathrm{Cl}+$ Gypsum & 150 & 100 & 240 \\
\hline
\end{tabular}

${ }^{1}$ Gypsum was applied together with all the treatments except control to offset the calcium and sulphate components of the some of the sources of the $\mathrm{K}, \mathrm{Na}$ and $\mathrm{Cl}$ nutrients. See text for details.

Table 2 Average soil Quick test results measured before sowing at Southbridge and Bankside sites. All units are in MAF QT units unless specified. The optimum nutrient requirements are for general crop production (McLaren \& Cameron 1996).

\begin{tabular}{lcccccccc}
\hline & $\begin{array}{c}\mathbf{p H}(\mathbf{m g} / \\
\mathbf{k g})\end{array}$ & $\begin{array}{c}\text { Olsen P } \\
(\mathbf{m g} / \mathbf{k g})\end{array}$ & $\mathbf{C a}$ & $\mathbf{M g}$ & $\mathbf{K}$ & $\mathbf{N a}$ & $\mathbf{C l}(\mathbf{m g} / \mathbf{k g})$ & $\begin{array}{c}\text { Available N (kg/ } \\
\text { ha) }\end{array}$ \\
\hline Bankside & 5.5 & 33 & 7 & 16 & 4 & 4 & 16 & 127 \\
Southbridge & 5.8 & 36 & 7 & 15 & 3 & 9 & 18 & 150 \\
Optimum & $5.8-6.0$ & $20-25$ & $4-10$ & $8-10$ & $5-8$ & $8+$ & $10-12$ & $100-150$ \\
\hline
\end{tabular}


and treatment structures for this experiment are similar to the Southbridge experiment (Table 1), with minor differences as described below. The Bankside experiment was replicated six times and cultivar 'Rivage' was planted at 80000 plants/ha. Seed were sown with a Stanhay $6 \mathrm{~m}$ vacuum drill on 1 November 2011 at a row spacing of $500 \mathrm{~mm}$. The row spacing is the standard with sowing contractors' machinery and hence the low plant population compared with Southbridge experiment, when an onion seeder was used at $375 \mathrm{~mm}$ row spacing. Plots were $2 \mathrm{~m}$ wide $\times$ $16 \mathrm{~m}$ long, giving at total experimental area of 0.173 ha. A soil test to $150 \mathrm{~mm}$ depth showed that the initial soil fertility was adequate, except for $\mathrm{K}$ and $\mathrm{Na}$ (Table 2). Basal fertiliser was applied at $250 \mathrm{~kg} \mathrm{DAP} / \mathrm{ha}$ and $15 \mathrm{~kg} / \mathrm{ha}$ boronate. Nitrogen as urea was applied once, at $70 \mathrm{~kg} \mathrm{~N} / \mathrm{ha}$ on 15 January 2012 . The nine fertiliser treatments were also broadcast to the relevant plots 2 days after sowing, similar fertilisers to Southbridge experiment being used as sources for $\mathrm{K}, \mathrm{Na}$ and $\mathrm{Cl}$.

Total rainfall at Bankside during the experimental period was $295 \mathrm{~mm}$. An additional $312 \mathrm{~mm}$ was added as irrigation throughout the experimental period. The mean temperature was $14.9^{\circ} \mathrm{C}$, with the highest temperature of $29.8^{\circ} \mathrm{C}$ recorded on 29 November 2011 and the lowest temperature of $-2.6^{\circ} \mathrm{C}$ recorded on 3 May 2012.

For both experiments, herbicides were applied using a 15-litre backpack Knapsack sprayer, on 2 and 10 November 2010 at Southbridge, and on 2 and 13 December 2011 at Bankside, to control a wide range of weeds. The herbicides applied were: Nortron ${ }^{\circledR}$ (a.i. 500 $\mathrm{g} / \mathrm{L}$ ethofumesate and $80 \mathrm{~g} / \mathrm{L}$ ethylene glycol) at $1 \mathrm{~L} /$ ha, Betanal ${ }^{\circledR}$ Forte (a.i. $160 \mathrm{~g} / \mathrm{L}$ each of phenmedipham and desmedipham, EC) at $1.2 \mathrm{~L} /$ ha and Goltix ${ }^{\circledR} \mathrm{DF}$ (a.i. $700 \mathrm{~g} / \mathrm{kg}$ metamitro) at $1 \mathrm{~kg} / \mathrm{ha}$ in $250 \mathrm{~L}$ of water. The insecticide Lorsban ${ }^{\circledR}$ (a.i. $500 \mathrm{~g} / \mathrm{L}$ chlorpyrifos $\mathrm{EC}$ and $490 \mathrm{~g} / \mathrm{L}$ hydrocarbon liquid) was applied at $1 \mathrm{~L} / \mathrm{ha}$ in $200 \mathrm{~L}$ of water 6 weeks after sowing in both experiments.

\section{Measurements}

At the final harvest, DM yield was determined from a $3 \mathrm{~m}^{2}$ quadrat (two rows by $4 \mathrm{~m}$ length) per plot on 27 April 2011 at Southbridge, and from a $2 \mathrm{~m}^{2}$ quadrat (two rows by $2 \mathrm{~m}$ length) on 28 May 2012 at Bankside. Plant density and total fresh weight per quadrat were determined in the field at each harvest. For both experiments, two plants were retained for determining DM yield and one plant for tissue mineral assessment. These were washed to remove soil and then separated into shoot (leaf and petiole) and bulb fractions. Fresh weights for the partitions were determined before being dried in a fan-forced oven at $90^{\circ} \mathrm{C}$ until constant weight.
The subsamples for tissue analysis were also separated into shoots and bulbs, crushed, immediately freezedried then finely ground with a Cyclone Sample Mill (Udy Corporation, Fort Collins, Colorado, USA) to pass through a $1 \mathrm{~mm}$ screen and analysed for nutrients by near infrared reflectance spectroscopy at Hills Laboratories Limited, (Hamilton, New Zealand). Effects of treatment on feed quality attributes were determined only for the Bankside crop. These included crude protein (CP; \%DM), acid detergent fibre (ADF; $\% \mathrm{DM})$ and neutral detergent fibre (NDF; \%DM), ash $(\% \mathrm{DM})$, metabolisable energy (ME; $\mathrm{MJ} / \mathrm{kg} \mathrm{DM})$, soluble sugars $(\mathrm{SS} ; \% \mathrm{DM})$ and dry organic matter digestibility (DOMD; \%DM).

\section{Data analyses}

Data representing total DM, nutrients concentration and uptake from each site were analysed by Analysis of Variance (ANOVA) in GenStat v. 14 (VSN International, Hemel Hampstead, UK). An indication of the variability associated with predicted means is provided by the least significant difference (LSD) at $\alpha$ $=0.05$. Where values show $\mathrm{P}<0.1$, a trend is indicated in the text. Three approaches were used to determine the effect of treatments (Table 1) on total DM, nutrient concentration and uptake. This was necessary to allow factorial comparison of nutrients independently of one another given the treatment structure described above. First, overall treatment effect (Treatment 1-9) was analysed to determine whether at least one of the treatments was different. Then the nutrients were partitioned on a presence/absence basis and analysed as a full factorial design for $\mathrm{K}, \mathrm{Na}$ and $\mathrm{Cl}$, nested within applied gypsum. For the feed quality responses, $\mathrm{Cl}$ was excluded leading to a full factorial of $\mathrm{K} \times \mathrm{Na}$ nested within gypsum. All mineral concentrations are expressed on a dry matter basis $(\mathrm{g} / \mathrm{kg} \mathrm{DM})$. Mineral uptake was calculated as mineral concentration $\times \mathrm{DM}$ yield (kg/ha).

\section{Results}

Plant establishment was more than $75 \%$ of drilled seeds at both sites: averaging 90000 plants/ha at Southbridge and 70000 plants/ha at Bankside. There were no significant differences in final DM yields among the treatments (1-9) $(\mathrm{P} \geq 0.23)$ at either site, averaging $32 \mathrm{t} \mathrm{DM} / \mathrm{ha}$ at Southbridge and $21 \mathrm{t} \mathrm{DM} / \mathrm{ha}$ at Bankside (Figure 1). However, under the presence/ absence factorial regime there was an interaction $(\mathrm{P}=0.042)$ between $\mathrm{K}$ and both $\mathrm{Cl}$ and $\mathrm{Na}$ (Figure 1) at Southbridge. Specifically, yield increased to $38 \mathrm{t} \mathrm{DM} /$ ha with $\mathrm{Na}$ and decreased to $30 \mathrm{t} \mathrm{DM} /$ ha with $\mathrm{Cl}$, in the presence of $\mathrm{K}$.

The bulbs contained about $70 \%$ of the total biomass 
(a) Southbridge 2010-11

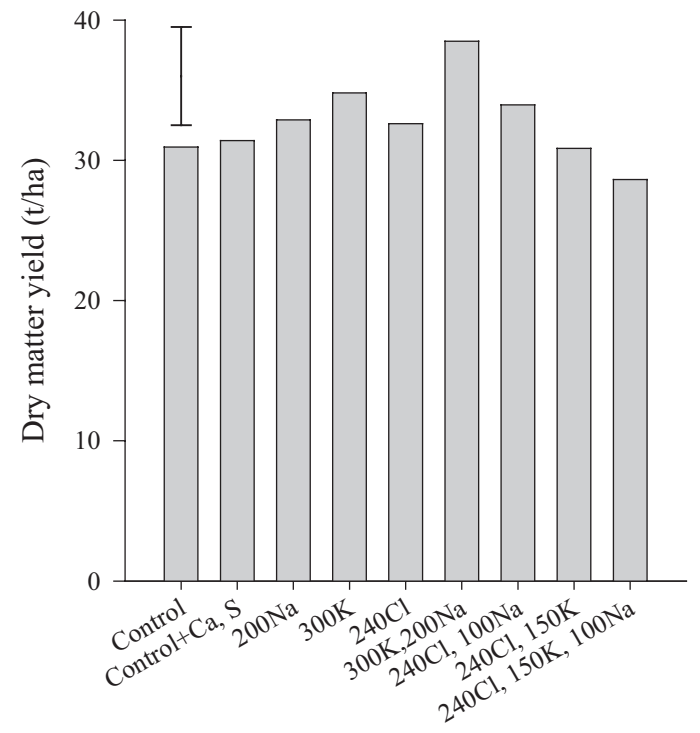

Fertiliser treatments $(\mathrm{kg} / \mathrm{ha})$ (b) Bankside 2011-12

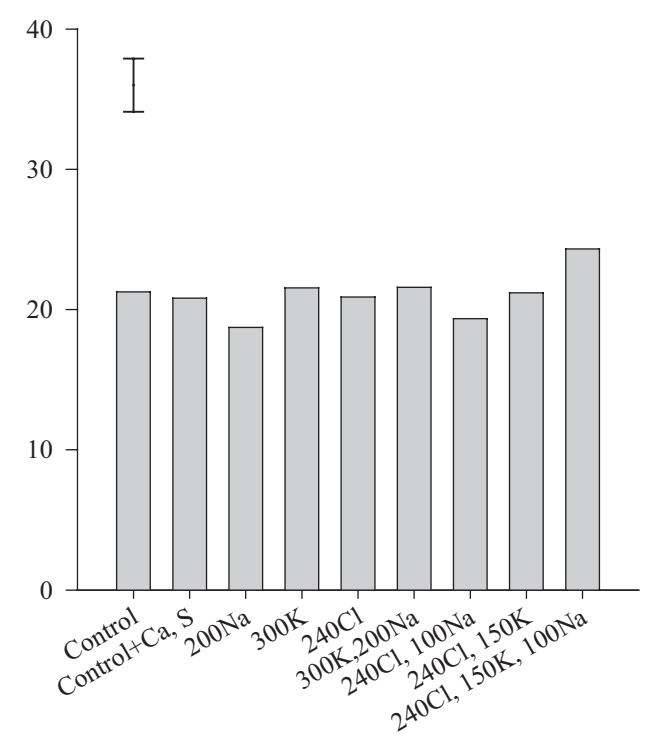

Fertiliser treatments $(\mathrm{kg} / \mathrm{ha})$

Figure 1 Total dry matter yield for fodder beet crops grown under different potassium (K), chloride (Cl), and sodium (Na) fertiliser rates and combinations at: (a) Southbridge and (b) Bankside in Canterbury in the 2011 and 2012 seasons. The numbers preceding the nutrient symbols are fertiliser amounts applied in $\mathrm{kg} / \mathrm{ha}$. Bar represents approximate LSD with 67 d.f. and $\alpha=0.05$.

at Southbridge and $83 \%$ at Bankside. Mean bulb DM was $17 \%$ at both sites. However, leaf DM at Bankside $(17 \%)$ was twice that at Southbridge.

\section{Mineral uptake and composition}

The overall mineral uptake at Southbridge of $522 \mathrm{~kg} \mathrm{~K} /$ ha, $300 \mathrm{~kg} \mathrm{Na} / \mathrm{ha}$ and $423 \mathrm{~kg} \mathrm{Cl} / \mathrm{ha}$ was $70 \%, 328 \%$ and $323 \%$ higher $(\mathrm{P}<0.001)$ than respective mineral uptake at Bankside (Figure 2). However, the application of K, $\mathrm{Na}$ and $\mathrm{Cl}$ had no significant effect $(\mathrm{P} \geq 0.12)$ on their respective mineral uptake at Southbridge (Figure 2a). At Bankside, Na uptake increased $(\mathrm{P}<0.001)$ by $42-$ $53 \%$ (Figure $2 \mathrm{bii}$ ) from an average of $60 \mathrm{~kg} / \mathrm{ha}$ for the control and control + gypsum treatments when $\mathrm{Na}$ was applied with or without other minerals. Application of $\mathrm{Cl}$ with or without other minerals increased $(\mathrm{P}<0.001)$ $\mathrm{Cl}$ uptake by $129-238 \%$ from an average of $58 \mathrm{~kg} / \mathrm{ha}$ for the control and control + gypsum treatments (Figure 2biii). However, $\mathrm{K}$ uptake was unaffected $(\mathrm{P}=0.12)$ by $\mathrm{K}$ application at Bankside.

The application of $\mathrm{K}, \mathrm{Na}$, and $\mathrm{Cl}$ fertiliser also increased the respective tissue mineral concentration at Bankside (Table 3), but not at Southbridge (data not shown). At Bankside, Na concentration in the bulbs was doubled $(\mathrm{P}<0.001)$ from $1.2 \mathrm{~g} / \mathrm{kg} \mathrm{DM}$ for the control and control + gypsum treatment to $2.4 \mathrm{~g} /$ $\mathrm{kg}$ DM for the Na-only treatment. The application of $\mathrm{Na}$ in presence of $\mathrm{K}$ or $\mathrm{Cl}$ increased $(\mathrm{P}<0.001) \mathrm{Na}$ mineral concentration in the bulbs by $67 \%$ and $125 \%$, respectively. However, the application of all three elements together had no effect $(\mathrm{P}=0.79)$ on Na mineral concentration. The leaf $\mathrm{Na}$ concentration also increased $(\mathrm{P}<0.001)$ with application of $\mathrm{Na}$ alone. However, leaf $\mathrm{Na}$ concentration was not affected by the presence of $\mathrm{K}$ or $\mathrm{Cl}$, but increased $(\mathrm{P}<0.017)$ by $60 \%$ in the presence of all three nutrients. The application of all the three fertiliser elements also increased $(\mathrm{P}=0.07)$ the $\mathrm{Na}$ uptake in the leaves. A similar observation was made for the application of $\mathrm{K}$ alone.

Application of $\mathrm{K}$ caused a marginal increase $(\mathrm{P}=0.06)$ in both leaf and bulb $\mathrm{K}$ concentration (Table 3). Potassium application also increased $(\mathrm{P}=0.04)$ bulb $\mathrm{K}$ uptake but had no effect $(\mathrm{P}=0.375)$ on leaf $\mathrm{K}$ content. Both tissue $\mathrm{Cl}$ mineral concentration (Table 3 ) and content (Figure 2) were increased $(\mathrm{P}<0.001)$ by the application of $\mathrm{Cl}$ fertilisers. As the bulbs contributed most of the total biomass, the total nutrient uptake was proportionally higher in the bulbs.

There was no interaction between $\mathrm{K}$ and $\mathrm{Na}$ fertilisers on the quality attributes of fodder beet crops (Table 4). There were no treatment effects on any of the variables for the leaf component. Sodium fertiliser had no effect 
(a) Southbridge 2010-11

(i) Potassium uptake

(b) Bankside 2011-12
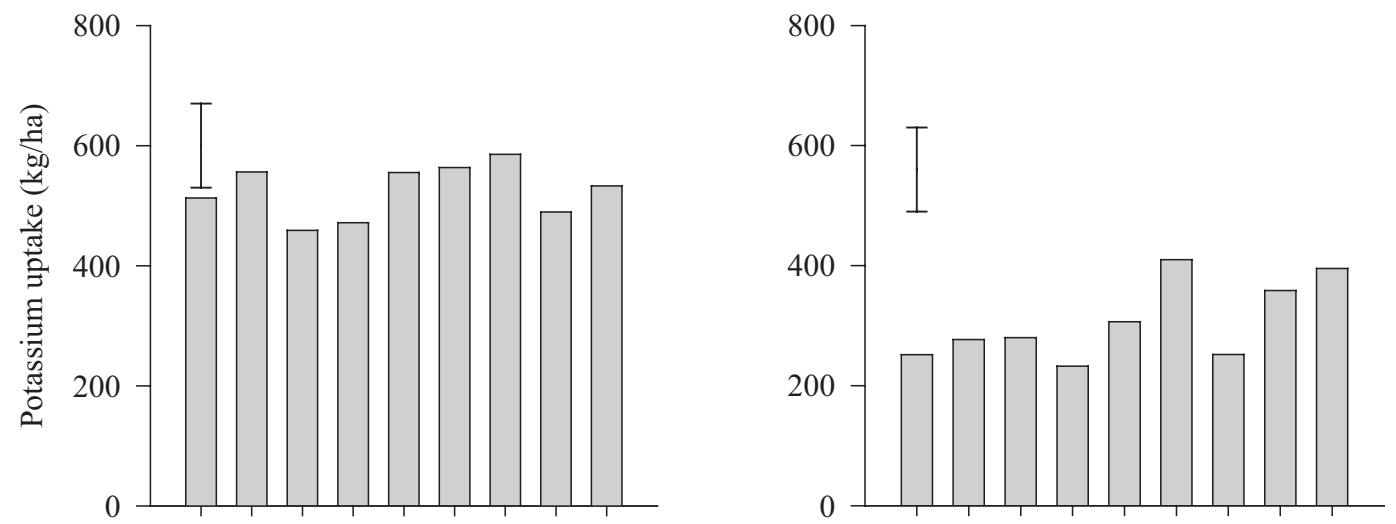

(ii) Sodium uptake
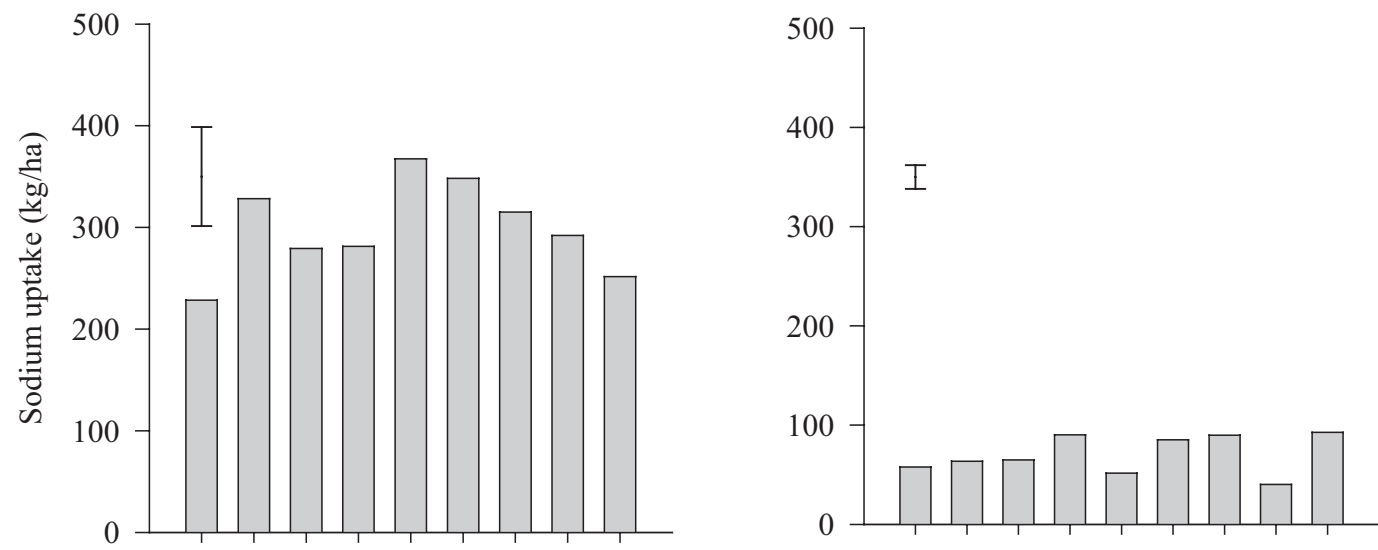

(iii) Chloride uptake

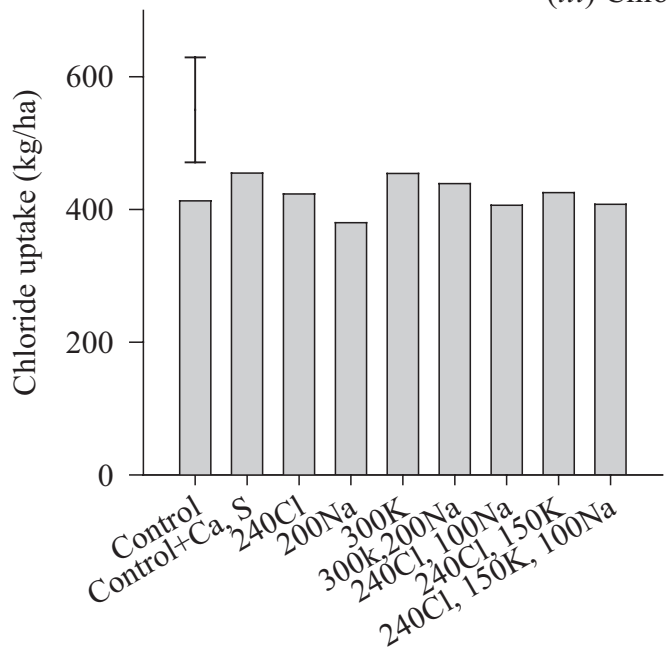

Fertiliser rate $(\mathrm{kg} / \mathrm{ha})$

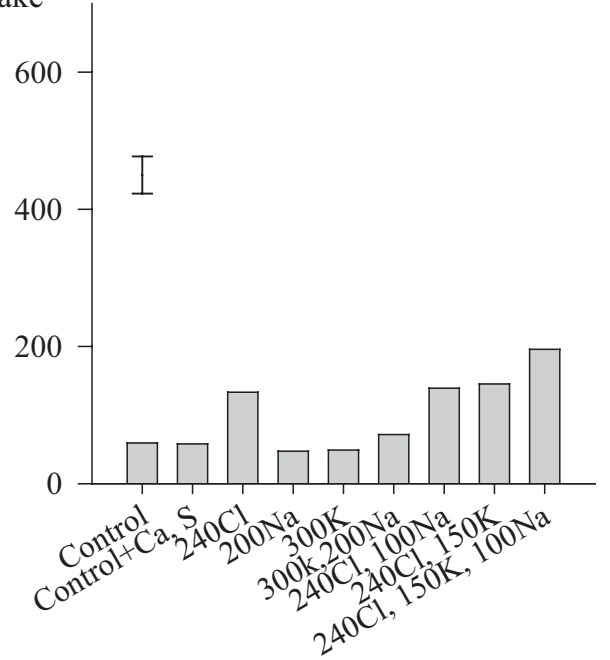

Fertiliser rate $(\mathrm{kg} / \mathrm{ha})$

Figure 2 Nutrient uptake (i) potassium (K) (ii) sodium (Na) and (iii) chloride (Cl) by fodder beet crops grown under different $\mathrm{K}$, Na and $\mathrm{Cl}$ fertiliser applications rates and combinations at: (a) Southbridge and (b) Bankside in Canterbury in the 2011 and 2012 seasons. The numbers preceding the nutrient symbols are fertiliser amounts applied in $\mathrm{kg} / \mathrm{ha}$. Bar represents approximate LSD with 67 d.f. and $\alpha=0.05$. 
on any of the measured quality indicators. However, $\mathrm{K}$ tended to depress the $\mathrm{CP}(\mathrm{P}=0.06)$, NDF $(\mathrm{P}=0.04)$ and ash content $(\mathrm{P}=0.09)$ of the bulbs and also tended to increase the DOMD $(\mathrm{P}=0.052), \mathrm{ME}(\mathrm{P}=0.065)$ and $\mathrm{SS}(\mathrm{P}=0.054)$. The $\mathrm{CP}, \mathrm{NDF}$ and total ash decreased by $7 \%, 14 \%$ and $24 \%$ when $\mathrm{K}$ was applied, compared with the average values of $8.40 \%, 9.70 \%$ and $4.50 \%$, respectively, for the control and control + gypsum treatments (Table 4). Crude protein, ADF, NDF and ash were greater $(\mathrm{P}<0.001)$ in the leaves than in the bulbs, by magnitudes of 1-2 times for $\mathrm{CP}$ and 3-5 times for the ADF, NDF and ash. In contrast, the DOMD, ME and SS were higher in the bulbs than the leaves, at 1.5-2 times for the DOMD and ME and 4-6 times for the SS.

\section{Discussion}

The overall yield differences of about $50 \%$ between the sites may be attributed to either cultivar differences

Table 3 The potassium $(\mathrm{K})$ sodium $(\mathrm{Na})$ and chloride $(\mathrm{Cl})$ tissue mineral concentration $(\mathrm{g} / \mathrm{kg} \mathrm{DM})$ for the bulb and leaf partitions of fodder beet crops grown at Bankside, Canterbury, in the 2011/12 season.

\begin{tabular}{|c|c|c|c|c|c|c|}
\hline \multirow[b]{2}{*}{ Treatment $^{1}$} & \multicolumn{3}{|c|}{ Bulb } & \multicolumn{3}{|c|}{ Leaf } \\
\hline & $\mathrm{K}$ & $\mathrm{Na}$ & $\mathrm{Cl}$ & $\mathrm{K}$ & $\mathrm{Na}$ & $\mathrm{Cl}$ \\
\hline Control & 9.7 & 1.1 & 0.7 & 21.7 & 10.1 & 12.4 \\
\hline Control+ Gypsum & 9.5 & 1.3 & 0.8 & 26.0 & 11.4 & 11.9 \\
\hline $200 \mathrm{Na}$ & 11.0 & 2.4 & 1.0 & 20.0 & 16.9 & 10.2 \\
\hline $300 \mathrm{~K}$ & 10.8 & 1.0 & 0.6 & 32.3 & 09.3 & 10.7 \\
\hline $240 \mathrm{Cl}$ & 11.3 & 1.6 & 2.1 & 22.2 & 10.1 & 26.3 \\
\hline $300 \mathrm{~K}, 200 \mathrm{Na}$ & 15.3 & 2.0 & 1.3 & 35.0 & 13.3 & 13.4 \\
\hline $240 \mathrm{Cl}, 100 \mathrm{Na}$ & 11.2 & 2.7 & 2.5 & 21.2 & 13.1 & 27.3 \\
\hline $240 \mathrm{Cl}, 150 \mathrm{~K}$ & 14.7 & 0.9 & 3.1 & 31.3 & 07.2 & 28.7 \\
\hline $240 \mathrm{Cl}, 150 \mathrm{~K}, 100 \mathrm{Na}$ & 14.2 & 1.6 & 3.4 & 28.2 & 16.0 & 33.5 \\
\hline $\operatorname{LSD}_{\alpha=0.05}$ & 04.3 & 0.82 & 1.5 & 11.6 & 3.5 & 7.3 \\
\hline F-pr & 0.063 & $<0.001$ & $<0.001$ & 0.069 & 0.001 & 0.001 \\
\hline
\end{tabular}

${ }^{1}$ The numbers preceding the nutrient symbols are fertiliser amounts applied in $\mathrm{kg} / \mathrm{ha}$.

Table 4 Feed quality (\% DM, unless stated otherwise) for the bulb and leaf partitions of fodder beet crops grown under different potassium $(\mathrm{K})$ and sodium $(\mathrm{Na})$ and chloride $(\mathrm{Cl})$ fertiliser rates at Bankside, Canterbury, in the 2011/12 season and the optimum concentrations for dairy cattle production (Grace et al. 2000; NRC 2001).

\begin{tabular}{|c|c|c|c|c|c|c|c|}
\hline Bulb & $\mathrm{CP}^{1}$ & ADF & NDF & Ash & DOMD & ss & ME (MJ/ kg DM) \\
\hline Control (C) & 9.70 & 6.8 & 10.73 & 5.37 & 91.20 & 55.40 & 14.60 \\
\hline C + Gypsum & 7.07 & 4.87 & 8.60 & 3.63 & 93.00 & 68.67 & 14.90 \\
\hline $\mathrm{K}$ & 7.80 & 4.77 & 8.30 & 3.40 & 93.70 & 74.93 & 14.97 \\
\hline $\mathrm{Na}$ & 10.03 & 6.63 & 11.00 & 5.50 & 90.83 & 56.70 & 14.53 \\
\hline $\mathrm{K} \times \mathrm{Na}$ & 8.90 & 4.3 & 8.93 & 4.03 & 92.87 & 69.23 & 14.87 \\
\hline $\operatorname{LSD}_{\alpha=0.05}$ & 2.33 & 4.21 & 3.1 & 2.95 & 3.25 & 23.14 & 0.53 \\
\hline Significance $(P=)$ & 0.066 & 0.13 & 0.044 & 0.094 & 0.052 & 0.054 & 0.065 \\
\hline \multicolumn{8}{|l|}{ Leaf } \\
\hline Control (C) & 13.53 & 23.93 & 32.37 & 21.6 & 62.93 & 11.9 & 10.07 \\
\hline C + Gypsum & 14.23 & 23.63 & 33.6 & 17.17 & 62.53 & 10.67 & 10.03 \\
\hline $\mathrm{K}$ & 14.93 & 21.93 & 30.9 & 18.4 & 63.97 & 13.67 & 10.23 \\
\hline $\mathrm{Na}$ & 12.87 & 23.4 & 32.7 & 18.4 & 64.63 & 13.5 & 10.33 \\
\hline $\mathrm{K} \times \mathrm{Na}$ & 12.93 & 24.2 & 35.83 & 21.33 & 60.7 & 10.67 & 9.7 \\
\hline $\operatorname{LSD}_{\alpha=0.05}$ & 5.4 & 4.05 & 6.97 & 7.73 & 8.63 & 6.17 & 1.39 \\
\hline Significance $(P=)$ & 0.67 & 0.64 & 0.71 & 0.96 & 0.60 & 0.79 & 0.60 \\
\hline Bulb $\times$ Leaf Interaction $(\mathrm{P}<)$ & 0.001 & 0.001 & 0.001 & 0.001 & 0.001 & 0.001 & 0.001 \\
\hline Optimum & $>12$ & $>21$ & $>33$ & 0.5 & $>70$ & $36-44$ & $10-11$ \\
\hline
\end{tabular}

${ }^{1} \mathrm{CP}=$ crude protein, $\mathrm{ADF}=$ acid detergent fibre, $\mathrm{NDF}=$ neutral detergent fibre, $\mathrm{DOMD}=\mathrm{dry}$ organic matter digestibility, $\mathrm{ME}=$ metabolisable energy, $\mathrm{SS}=$ soluble sugars 
and/or seeding rates. There are no published DM yield data comparing fodder beet cultivars available in New Zealand, but the current results seems to suggest that 'Colosse' yields better than 'Rivage' in Canterbury region of New Zealand. However, the results of 19-35 $t$ $\mathrm{DM} /$ ha reported by Matthew et al. (2011) suggests that 'Rivage' can yield as much as 'Colosse'. Moreover, the average DM yields of $32 \mathrm{t} \mathrm{DM/ha} \mathrm{for} \mathrm{'Colosse'} \mathrm{at}$ Southbridge and $21 \mathrm{t} \mathrm{DM/ha} \mathrm{for} \mathrm{'Rivage'} \mathrm{at} \mathrm{Bankside}$ were within the range reported by Matthew et al. (2011) for 'Rivage' at Hawke's Bay in the North Island of New Zealand. The wider row spacing of $500 \mathrm{~mm}$ at Bankside ('Rivage') compared with the $375 \mathrm{~mm}$ rows at Southbridge ('Colosse') meant that canopy closure was not achieved and there were lower DM yields. This could explain the yield differences between the sites.

The differences in sowing rates and subsequent fodder beet establishment of 9 plants $/ \mathrm{m}^{2}$ at Southbridge and 7 plants $/ \mathrm{m}^{2}$ at Bankside could also have contributed to the differences in DM yields between the sites. Plant density had been shown to influence DM yield in fodder beet crops. In Ireland, Storey \& Barry (1983) have reported a $7-14 \%$ DM yield decrease as the plant density decreased from 6 to 4 plants $/ \mathrm{m}^{2}$. Similarly, in New Zealand, Martin \& Drewitt (1984) have reported a $20 \%$ decrease in fodder beet fresh weight as plant density decreased from 7 to 6 plants $/ \mathrm{m}^{2}$.

The proportions of bulb (0.83) and leaf (0.17) to total DM yield, and their respective DM\% of about $17 \%$ at Bankside were similar to those reported by Matthew et al. (2011) and Goh \& Magat (1989) for 'Rivage' and 'Trestel' fodder beet cultivars, respectively. The differences in the mean leaf DM\% between the sites in the current experiments can be related to the different cultivars used, as Matthew et al. (2011) used the same cultivar as at Bankside with the same results.

High mineral uptake at Southbridge than Bankside could be attributed to the low mineral concentration (Table 3) and less DM yield (Figure 1) at Bankside compared with Southbridge (Chakwizira et al. 2012). At both sites the concentration of the minerals was consistently greater $(\mathrm{P}<0.001)$ in the leaf than in the bulbs (Table 3; Chakwizira et al. 2012). This is consistent with the reports by Goh \& Magat (1989) and Draycott et al. (1974). The increase in $\mathrm{Cl}$ concentration with application of $\mathrm{Cl}$ fertilisers was also consistent with the reports by Goh \& Magat (1989). The observation that the amount of nutrient applied mostly meant higher uptake of the respective nutrient was supported by the findings of Magat \& Goh (1988). The nutrient concentrations reported for both Southbridge (Chakwizira et al. 2012) and Bankside (Table 3) crops were on average within the NRC (2001) dietary recommendation for lactating cows of about 10,2 and
$2.8 \mathrm{~g} / \mathrm{kg} \mathrm{DM}$ for $\mathrm{K}, \mathrm{Na}$ and $\mathrm{Cl}$, respectively.

Soil type and climatic effects have been cited as major factors contributing to variable yields and mineral uptake in fodder beet crops (Magat \& Goh 1988). Both the Southbridge and Bankside experiments were fully irrigated and experienced similar mean temperatures and therefore, it was likely that the differences in DM yield, mineral concentrations and uptake between the experiments may be due to background soil type or cultivar responses. The soils at Bankside are the stony sandy loams with limited depth (McLaren \& Cameron 1996) compared to the deeper Pallic soils at Southbridge. This could have effected water and nutrient retention and subsequent availability to the crops; both were less at the Bankside site.

The nutritive qualities reported at Bankside (Table 4) are consistent with those previously reported (Clark et al. 1987; Gibbs 2011; Matthew et al. 2011). Moreover, with the bulb proportions in excess of $80 \%$ of the total DM, the low bulb nutritional values can result in suboptimal CP content for wintering of dairy animals. Gibbs (2011) has reported a minimum CP requirement of $12 \%$ and in all cases this was not reached, even after allowing for leaf material that may be fed in situ. The same was true for the other quality attributes whose concentrations were low in the bulbs, and would be suboptimal if fed without supplementation. Lower CP and fibres resulting from the low concentrations in the bulbs (Table 4), can be potentially problematic for ration balancing of ruminant feeding (Matthew et al. 2011) because of the high SS, low CP and low fibre contents (Table 4). The combination of low fibre and high SS concentrations may reduce rumen $\mathrm{pH}$ and put animals at risk of rumen acidosis (Nichol et al. 2003). Conversely, the low $\mathrm{CP}$ (or nitrogen $(\mathrm{N})$ concentration $=\mathrm{CP} / 6.25$; Metson \& Saunders 1978) could result in reduced total nitrogen excreted by animals to the environment, compared to the high $\mathrm{N}(\mathrm{CP})$ concentration crops such as winter fed brassicas e.g. kale (Fletcher \& Chakwizira 2012). The overall low CP may thus not necessarily be bad results considering the animals being fed the crop during this time of the year are under maintenance feeding.

\section{Conclusions}

- Fertiliser treatments had no effect on DM yield at both Southbridge and Bankside. Mineral concentrations were higher in the leaves than bulbs. Moreover, the higher bulb proportion $(>70 \%$ of total DM) may mean low overall nutrient availability to feeding dairy animals. Both $\mathrm{Na}$ and $\mathrm{Cl}$ application increased their respective tissue mineral concentration and uptake at Bankside but not at Southbridge. 
- Fertiliser application effect on feed quality attributes at Bankside was inconsistent; $\mathrm{K}$ tended to depress $\mathrm{CP}, \mathrm{NDF}$ and ash content of the bulbs and increase ME and soluble sugars, while $\mathrm{Na}$ had no effect on any of the measured quality attributes. However all measured attributes differed with crop part. For example, CP, ADF, NDF and ash content were higher in the leaves than the bulbs and the DOMD, ME and soluble sugars were higher in the bulbs than the leaves.

- Overall, the fibres and CP were lower than the minimum recommended for dairy cows that are either in late pregnancy or early lactation. The combination of low fibre and high SS concentrations may reduce rumen $\mathrm{pH}$ and put animals at risk of rumen acidosis.

\section{ACKNOWLEDGEMENTS}

The authors would like to thank Ballance Agri-Nutrients for financial support. We also thank the Rakaia Island Dairies (Southbridge) and Calvin Ross (Bankside), who allowed us to undertake the experiments on their farms.

\section{REFERENCES}

Chakwizira, E.; Fletcher, A.L.; Meenken, E.; Johnstone, P.; Maley, S.; Arnold, N.; Armstrong, S.; George, M.; Sim, R.E.; Minchin, R.; Morton, J.D.; Stafford, A.D. 2011. Dry matter response of swede crops to phosphorus (P) and nitrogen $(\mathrm{N})$ application in Southland and central North Island regions of New Zealand. Proceedings of the Agronomy Society of New Zealand 41: 23-37.

Chakwizira, E.; Maley, S.; George, M.; Hubber, R.; Morton, J.D.; Stafford, A.D. 2012. Effects of potassium, sodium and chloride fertiliser on fodder beet yield and mineral composition. pp. 431-434 In: Proceedings of the 5th Australasian Dairy Science Symposium. Ed. Jacobs, J. National Dairy Alliance, Melbourne, Australia.

Clark, P.; Givens, D.I.; Brunnen, J.M. 1987. The chemical composition, digestibility and energy value of fodder-beet roots. Animal Feed Science and Technology 18: 225-231.

Draycott, A.P.; Durrant, M.J.; Webb, D.J. 1974. Effects of plant density, irrigation and potassium and sodium fertilizers on sugar beet: I. Yields and nutrient composition. Journal of Agricultural Science 82: 251-259.

Fletcher, A.L. and Chakwizira, E. 2012. Developing a critical nitrogen dilution curve for forage brassicas. Grass and Forage Science. 67: 13-23.

Gibbs, J. 2011. Wintering dairy cows on fodder beet. pp. 230-238 In:Proceedings of the South Island Dairy Event, Invercargill.
Goh, K.M.; Magat, S.S. 1989. Sodium chloride increases the yield of fodder beet (Beta vulgaris L.) in two New Zealand soils. New Zealand Journal of Agricultural Research 32: 133-137.

Gowers, S.; Butler, R.; Armstrong, S.D. 2006. Yield comparisons of old and new cultivars of swedes (Brassica napus ssp. napobrassica) in Southland, New Zealand. New Zealand Journal of Crop and Horticultural Science 34: 109-114.

Grace, N.D.; Craighead, M.; Watt, B. 2000. The macro- and micro-element content of swedes and kale in Southland, New Zealand, and the effect of trace element-amended fertilisers on their $\mathrm{Co}$, $\mathrm{Se}$, and $\mathrm{Cu}$ concentrations. New Zealand Journal of Agricultural Research 43: 533-540.

Hedley, C.B.; Bradbury, S.; Ekanayake, J.; Yule, I.J.; Carrick, S. 2010. Spatial irrigation scheduling for variable rate irrigation. Proceedings of the New Zealand Grassland Association 72: 97-102.

McLaren, R.G.; Cameron, K.C. 1996. Soil science: sustainable production and environmental protection. 2nd ed. Oxford University Press, Auckland. 218 pp.

McLaren, R.G.; Rooney, C.P.; Condron, L.M. 2009. Control of lead solubility in soil contaminated with lead shot: effect of soil moisture and temperature. Soil Research 47: 296-304.

Magat, S.S.; Goh, K.M. 1988. Effects of chloride fertilizers on yield and uptake of chloride, potassium and sodium by fodder beet (Beta vulgaris L.) in two New Zealand soils. Journal of Agricultural Science 111: 207-216.

Martin, R.J.; Drewitt, E.G. 1984. Effects of sowing date and harvest date on yields of irrigated sugar beet and fodder beet on 2 soil types in Canterbury. New Zealand Journal of Experimental Agriculture 12: 185-195.

Matthew, C.; Nelson, N.J.; Ferguson, D.; Xie, Y. 2011. Fodder beet revisited. Proceedings of the Agronomy Society of New Zealand 41: 39-48

Metson, A.J. and Saunders, W.M.H. 1978. Seasonal variations in chemical composition of pasture. New Zealand Journal of Agricultural Research. 21: 355-364.

Nichol, W.; Westwood, C.; Dumbleton, A.J.; Amyes, J. 2003. Brassica wintering for dairy cows: overcoming the challenges. Proceedings of the South Island Dairy Event 154-172. 
NRC. 2001. Nutrient requirement of dairy cattle, 7th ed. National Research Council, National Academy Press, Washington, DC. 408 pp. [available online; accessed 11 March 2013]

Stephen, R.C.; Kemp, T.N.; Todd, B.W. 1980. A preliminary investigation into the fertiliser requirements of fodder beet (Beta vulgaris L. Cv Monoblanc) on some Canterbury soils. Proceedings of the Agronomy Society of New Zealand 10: 5-8.
Storey, T.; Barry, P. 1983. The response of three fodder beet cultivars to drilling to a stand. Irish Journal of Agricultural Research: 47-57.

Wilson, D.R.; Reid, J.B.; Zyskowski, R.F.; Maley, S.; Pearson, A.J.; Armstrong, S.D.; Catto, W.D.; Stafford, A.D. 2006. Forecasting fertiliser requirements of forage brassica crops. Proceedings of the New Zealand Grassland Association 68: 205-210. 
